\title{
Analyzing Elementary English Teachers' Pronunciation Errors: Are We Intelligible?
}

\section{Dedi Febrianto ${ }^{1}$}

\author{
DOI: 10.35445/alishlah.v13i3.814
}

\begin{abstract}
Article Info
Keywords:

Error Analysis;

Pronunciation;

Teachers

Elementary school

Abstract

Error analysis on students' language performance has been massively discussed, yet few studies focused on teachers' errors. Meanwhile, one of the main causes of students' errors is the errors transferred from teachers. As the learners used to imitate their teachers sounds' production, EFL teachers need to minimize errors when teaching at elementary school concerning the learners' best period to acquire and learn a foreign language. The present study investigates EFL teachers' pronunciation errors, specifically to find out the forms and causes of pronunciation errors in segmented vowels produced by the teachers. The research participants are 20 English teachers selected from various public and private elementary schools in Yogyakarta who were invited to pronounce 62 English words. The teachers were also required to fill out a questionnaire to find out external factors which are assumed can trigger the errors. The findings delineated that the teachers produced various forms of pronunciation errors in English vowels. The causes of errors lie in interlingual transfer, intralingual transfers, pronunciation differences between graphemes and sounds, hypercorrection, and words similarity. The external factors are also scrutinized, which include educational background and teachers' lack of English practice. The study suggests that elementary EFL teachers in Indonesia should improve their pronunciation by frequently practicing and having intensive pronunciation training to teach better English to their learners.
\end{abstract}

Kata kunci:

Analisis Kesalahan;

Pengucapan;

Guru

Sekolah Dasar

\begin{abstract}
Abstrak
Analisis kesalahan bahasa murid telah diteliti secara masif, namun sedikit studi yang berfokus pada kesalahan guru. Sementara itu, salah satu penyebab utama kesalahan murid adalah kesalahan yang ditransfer guru. Guru Bahasa Inggris perlu meminimalisasi kesalahan terutama saat mengajar di SD karena murid terbiasa meniru ucapan gurunya sedangkan mereka berada pada periode terbaik untuk memperoleh dan belajar bahasa asing. Penelitian ini menyelidiki kesalahan pengucapan bahasa Inggris pada guru, khususnya mengetahui bentuk dan penyebab kesalahan pengucapan pada bunyi vokal. Penelitian ini melibatkan 20 guru bahasa Inggris dari berbagai SD negeri dan swasta di Kodya Yogyakarta. Guru diminta mengucapkan 62 kata bahasa Inggris, serta mengisi kuesioner untuk mengetahui faktor eksternal yang dianggap dapat memicu kesalahan. Hasil studi menunjukkan guru memproduksi berbagai bentuk kesalahan pengucapan. Penyebab kesalahan adalah transfer interlingual, transfer intralingual, perbedaan pengucapan antara grafem dan bunyi, hiperkorek, dan kemiripan kata. Selain itu juga disebabkan oleh faktor eksternal seperti latar belakang pendidikan dan kurangnya praktik bahasa Inggris. Studi ini menyarankan guru Bahasa Inggris SD perlu meningkatkan kemampuan pengucapan dengan sering mempraktikkan dan mengikuti pelatihan pengucapan intensif sehingga dapat mengajar bahasa Inggris dengan lebih baik.
\end{abstract}

\footnotetext{
${ }^{1}$ Politeknik APP Jakarta, Kementerian Perindustrian RI, Jakarta, Indonesia

Email: dedi-febrianto@kemenperin.go.id
} 


\section{INTRODUCTION}

Based on the 2013 curriculum, English is not a compulsory subject in elementary school in Indonesia, yet it is still taught to the students for several reasons. One of which is the parents' demand for the school because they believe that their children must be exposed to English as early as possible to have a better future (Jazuly \& Indrayani, 2018). In addition, English is considered the primary foreign language and is more relevant than any other foreign language taught in Indonesia (Haidara, 2016). However, it is very distinct from Indonesian students' first languages ranging from sounds, spelling, and the value of foreign language cultures. The teacher needs to understand such differences so that learning can be justified. Hence, English teaching at elementary schools in Indonesia must be taught by teachers with a good command of English.

Zein (2017) explains two types of English teachers at elementary schools in Indonesia: generalist and specialist teachers. The generalist teachers are those teachers who did not undertake English education with their bachelor's degree, while the specialists are those who graduated from English education. Moreover, most teachers, specifically those from eastern parts of Indonesia, have poor and fair English professional competency (Sikki et al., 2013). This generates many problems in English teaching at elementary schools in Indonesia, ranging from teaching methodology to the teachers' English skills performance, including pronunciation, speaking, etc.

In teaching English skills (speaking, listening, reading, and writing), teachers inevitably will tackle questions and problems related to pronunciation as it can not be separated from teaching any of those skills. Moedjito \& Harumi (2008) reveals that English teachers in Indonesia can deal with students' mispronunciation problems, mainly because teaching pronunciation is insufficient. Moreover, most English language teaching in Indonesia tend to focus more on vocabulary and grammar than on pronunciation (Moedjito, 2017). The emphasis on grammar may bring students difficulties in acquiring correct pronunciation (Al Mafalees, 2020). To avoid this, the way and the amount of time of teaching pronunciation, as well as the students' problems in English pronunciation, need to be tackled seriously, and English teachers should give an appropriate portion and attention to pronunciation teaching (Osatananda \& Salarat, 2020).

Çakır \& Baytar (2014) reveal that teachers in this era need to increase their phonological understanding, and they have to know that students cannot learn pronunciation independently. Instead, teachers must spend special efforts to facilitate students with proper pronunciation teaching. Besides, teachers are responsible for teaching students new sounds, words, and phrases and giving suitable materials for understandable pronunciation in their EFL class (Pourhosein Gilakjani \& Sabouri, 2016). Primarily, teachers at elementary schools should have proper English pronunciation as their students are at their best to learn and acquire any foreign languages. It is supported by the Critical Period Hypothesis ( $\mathrm{CPH}$ ) in learning the second language, whereas the second language is easier to master at elementary school. According to Penfield and Robert (1959), the critical period is likely to terminate much sooner than puberty, around nine. However, Lenneberg (1967) believed this critical period spanned from the age of two through puberty. In addition, Brown (2008) concludes that most of the facts in learning the second language indicate that when people reach puberty, they will not get the authentic pronunciation or native-like. At this age, the influence of the mother tongue is not very significant.

Nevertheless, Indonesian English teachers are reported not very fluent in English (Renandya et al., 2018), and they feel that pronunciation is not an easy thing for them (Moedjito, 2016). Demirezen (2007) pinpoints that several EFL teachers have a heavy foreign accent so that when they speak English, it sounds unnatural. This explains that the teachers have inaccurate pronunciation and sound unnatural, contributing to inefficient teaching they hold. Moreover, the teachers' error can cause the same errors to students because students are used to absorbing their teachers' way of pronunciation, also known as imitating (Pateda, 1989).

Though error and mistake are synonymous, differentiating both of them is worth doing. Brown (2008) states that a mistake is commonly triggered by performance factors such as a slip of 
the tongue, emotional tense, doubtfulness, and other performance failures which occur unsystematically. It means that when a mistake is made, the speaker can still correct it by himself. Meanwhile, an error is a language deviation that reflects one's competency and occurs consistently and systematically (Brown, 2008; Dulay et al., 1982) due to the learners' lack of knowledge on what is correct (Ellis, 1997). An error cannot be corrected immediately because it is produced in an unconscious condition. In other words, an error is made due to one's ignorance of certain language aspects.

The errors made by the teachers can take place in any aspect of language, including pronunciation which occurs in certain sounds in the phonological system of a language. The preliminary study found that pronunciation errors produced by elementary English teachers in Yogyakarta generally occur in vowel sounds.

Table 1. Data findings in the preliminary study

\begin{tabular}{ll}
\hline Words & As Recorded \\
\hline quiet [kwarət] & quite [kwait] \\
later [leitə(r)] & letter [letə(r)] \\
food [fu:d] & foot [fot] \\
tie [tai] & tea [ti:] \\
bread [bred] & [brid] \\
one hundred [w nhh $\Lambda$ ndrəd] $_{\text {circle [s3:kl] }}$ & [wan handrid] \\
notebook [nəotbok] & [si(r)kl] \\
\hline
\end{tabular}

From the table, vowels are the sounds which mostly mispronounced by elementary English teachers. The diphthong [eI] as in later [leitə(r)] is pronounced as monophthong [e] because the participant's first language (Javanese) does not recognize any diphthongs in the first syllable of a word as it is difficult for them to pronounce it (Marsono, 2013). The error in such pronunciation can confuse the listeners for another word, namely the letter [letə(r)]. Likewise, the triphthong [arə] in quiet [kwarət] is pronounced only with diphthong [aI] and can be misunderstood to another word that is quite [kwart], and long monophthong [u:] as in food [fu:d] is pronounced as short monophthong [v]. If elementary school English teachers in Indonesia continue to make such errors, the students' English pronunciation will be problematic.

Many researchers have largely done studies on error analysis in pronunciation. Mulansari et al. (2014) investigated the Indonesian students' errors in producing English vowel sounds and concluded that the students have a high frequency of pronunciation errors. Begum \& Hoque (2016) discussed that Bangladeshi students had encountered correct pronunciation, caused mainly by their mother tongue interference. Ramasari (2017) confirmed that English teachers are responsible for evaluating and correcting the students' pronunciation errors by identifying the consistent errors. Irianto et al. (2018) showed that Indonesian students have difficulties in pronouncing consonants that do not exist in their L1 (first language), such as [ $\theta]$ and [ð]. Then Alzinaidi \& Abdel Latif (2019) examined that Arab EFL students made many mistakes in pronouncing hard English consonants as an impact of their English proficiency level. Lastly, Arikan \& Yilmaz (2020) analyzed problematic English sounds made by 66 pre-service English teachers and found errors on consonants or vowels made by these ELT graduated students in Turkey. Their research is conducted with the belief that the learners' primary input is the teacher, and the learners' errors may be caused by the input they get in the learning environment.

Previous studies on error analysis in pronunciation mainly discussed the types of errors and focused the analysis on students' errors. Meanwhile, little research has been done on elaborating the causes of errors, primarily on teachers' errors. Hence, the present study is carried out and concentrated on the teachers' pronunciation errors of English segmented vowels sounds. It is worth exploring more as the teachers' errors are believed to be one of the major causes of the learners' errors, leading to the failure of the learners to master English well. The teachers' 
pronunciation errors can be transferred to the students (Hunt-Gómez \& Navarro-Pablo, 2020), which can generate similar errors, especially to the young learners, as they used to imitate their teachers' sounds production. Besides, the teachers' errors have not been further investigated in previous researches. In addition, the causes of errors in pronunciation remain scarce in the discussion. As the findings in the preliminary study prove that pronunciation error produced by elementary English teachers generally occurs in vowel sounds, this study is limited only to the teachers' pronunciation errors of vowels sounds and ignores any errors in consonants. Therefore, the purposes of this study are to identify the forms of pronunciation errors in English vowels produced by teachers teaching English at Indonesian elementary schools and to explore the causes of the produced errors.

\section{METHODS}

The study is in error analysis which investigates the pronunciation errors made by elementary English teachers in Yogyakarta Municipality, Indonesia. It employs a descriptive qualitative method using a case study (Creswell, 2014) which tries to deeply describe pronunciation errors involving participants teaching at several elementary schools in the same city.

Before collecting the data, the word list is arranged to assume that elementary English teachers' chosen words tend to be incorrectly pronounced so that data variations can be obtained. Each selected word reflects one vowel sound with its distribution in a position, whether in the beginning, middle, and the end of the word. After that, it was tested for several people to estimate whether the word list was effective for measuring pronunciation errors. This trial resulted in 62 words containing each English vowel sound in each position as the research instrument. Besides, a simple questionnaire was also designed to contain participants' personal information, including their educational background, mother tongues, years of teaching, etc., to investigate external factors (non-linguistic) that could trigger errors.

After preparing the research instruments, the participants were selected by using purposive sampling. The criteria are elementary school English teachers teaching in Yogyakarta Municipality, having good speech organs, no hearing loss, and aged between 20 and 45 years. Based on these criteria, there were 20 teachers randomly selected from 15 public and private Elementary schools in Yogyakarta municipality.

The research data were captured through recording techniques (Kesuma, 2007). The teachers were asked to pronounce the word list and were recorded. It is worth mentioning that the recording process used SONY ICD-PX312 Digital Voice Recorder. Before recording, the teacher was asked to understand the list of words being tested to prevent mistakes in understanding the words to be pronounced and to fill out the questionnaire. Once the research instruments were understood, the recording process was carried out.

The data analysis was begun by transcribing the recorded data phonetically by using International Phonetic Alphabet (IPA) symbol. Each error found is continuously referred to the standard English language based on the RP (Received pronunciation) standard. RP is considered the best and most appropriate English accent used in pronunciation teaching and the most discussed accent globally, which phoneticians have used in their writings for centuries (Skandera \& Burleigh, 2005). Thus, the pronunciation of elementary school English teachers can be identified by paying attention to the pronunciation of vowel sounds that follow the RP standard. In contrast, the pronunciation of vowel sounds that are not following is categorized as incorrect pronunciation. Therefore, the speech parameter used is a phonetic transcription in an English dictionary by Hornby (1995) that already follows the RP standard. In listening to the data, the researcher used IPA Help 2.1 application to identify which vowel sound is pronounced by the teacher. From the results of this transcription, the forms of vowel pronunciation can be obtained. After that, each error classified firstly in a table is elaborated. Each form is explained based on the position of the error and the presence or absence of other words or different meanings embedded in the error. The 
data analysis was then continued by identifying the causes of vowel pronunciation errors. The causes analyzed from the form of errors that occurred are categorized as linguistic factors. Meanwhile, other causes are also identified from the questionnaire by devising them as nonlinguistic factors. After that, each factor is described along with the example of the error found.

\section{FINDINGS AND DISCUSSION}

\section{The Forms of the Pronunciation Errors}

The analysis found that there are various vowels pronunciation errors produced by the participants, which cover all types of vowel sounds, namely monophthong, diphthong, and triphthong (Roach, 1998). The errors in monophthong mostly occur on the sounds that do not exist in Indonesian and Javanese. They are [i:], [æ], [a:], [u:], [o], [^], [3:], and [o:]. Meanwhile, most of the errors in diphthong are pronounced as monophthong. This deviation is known as monophthongization, which changes sounds from diphthong to monophthong (Utulu, 2014). In addition, errors in triphthong frequently occur in [v] and [I] in the middle of triphthong that is pronounced as glides [w] and [j]. Besides, several errors produced could lead to different words which surely have different meanings. However, due to the limited space provided, only several samples of errors can be displayed.

Table 2. Samples of Data Findings on the Forms of Errors

\begin{tabular}{|c|c|c|c|c|}
\hline Vowels Type & $\begin{array}{l}\text { Orthographic } \\
\text { transcription }\end{array}$ & Phonetic transcription & $\begin{array}{c}\text { Produced } \\
\text { sounds }\end{array}$ & Vowels Errors \\
\hline \multirow[t]{12}{*}{ Monophthong } & wheel & [wi:l] & [wil $]$ & {$[\mathrm{i}:] \rightarrow[\mathrm{I}]$} \\
\hline & idiot & [Idiət] & [ardiət] & {$[\mathrm{I}] \rightarrow[\mathrm{aI}]$} \\
\hline & breath & [bre $\theta]$ & [bri:t] & {$[\mathrm{e}] \rightarrow[\mathrm{i}:]$} \\
\hline & cat & [kæet] & [ket] & {$[æ] \rightarrow[\mathrm{e}]$} \\
\hline & car & [ka:] & [kar] & {$[\mathrm{a}:] \rightarrow[\mathrm{a}]$} \\
\hline & cook & {$[\mathrm{kuk}]$} & {$[\mathrm{kuk}]$} & {$[v] \rightarrow[\mathrm{u}]$} \\
\hline & ooze & [u:z] & {$[\mathbf{o z}]$} & {$[\mathrm{u}:] \rightarrow[\mathrm{o}]$} \\
\hline & hot & [hot] & [hot] & {$[\mathrm{p}] \rightarrow[\mathrm{o}]$} \\
\hline & dawn & [do:n] & [daon] & {$[\mathrm{o:}] \rightarrow[\mathrm{av}]$} \\
\hline & utter & {$[\Delta t \partial]$} & [atər] & {$[\Lambda] \rightarrow[\mathrm{a}]$} \\
\hline & earth & {$[\mathbf{3 :} \theta]$} & [ord] & {$[3:] \rightarrow[ə]$} \\
\hline & alarm & [əla:m] & [alaram] & {$[\partial] \rightarrow[\mathrm{a}]$} \\
\hline \multirow[t]{8}{*}{ Diphthong } & vary & [veəri] & [feri] & {$[\mathrm{e}] \rightarrow[\mathrm{e}]$} \\
\hline & era & [Іәrə] & [era] & {$[\mathrm{I} ə] \rightarrow[\mathrm{e}]$} \\
\hline & curious & [kjoərıəs] & [kərıəs] & {$[$ [ə] $\rightarrow[\partial]$} \\
\hline & great & [greit] & [grit] & {$[\mathrm{eI}] \rightarrow[\mathrm{i}]$} \\
\hline & tie & [tai $]$ & [ti:] & {$[\mathrm{aI}] \rightarrow[\mathrm{i}:]$} \\
\hline & go & [gəひ] & [go] & {$[\partial \mho] \rightarrow[0]$} \\
\hline & oil & [oll $]$ & [oil] & {$[\mathrm{OI}] \rightarrow[\mathrm{oi}]$} \\
\hline & house & [haos] & [hous] & {$[\mathrm{av}] \rightarrow[\mathrm{ou}]$} \\
\hline \multirow[t]{5}{*}{ Triphthong } & layer & [leı $]$ & [lejər] & [ен] $\rightarrow$ [ејə] \\
\hline & giant & [dzarənt] & [dzajənt] & [агə] $\rightarrow$ [ајə] \\
\hline & lower & [ləбə] & [lowər] & [әขә] $\rightarrow$ [owe] \\
\hline & royal & [rorəl] & [rojal] & [эг] $\rightarrow$ [эјә] \\
\hline & flower & [flavo] & [flawər] & [avə] $\rightarrow[$ awə] \\
\hline
\end{tabular}

The table shows that there are various errors in monophthongs. Some of the errors can be misunderstood to different words, and this can drive the listener into confusion. The first error

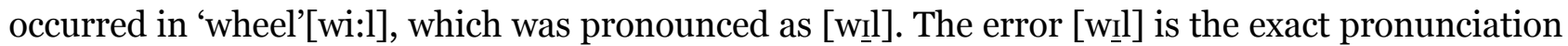
of the word "will', so that listener can misunderstand the intended word pronounced by the speaker. Another error is in 'dawn' [do:n] which was pronounced as [davn]. This error will make the listener think of the word 'down' since it is exactly pronounced [davn] as the error produced. 
The errors in diphthongs, which are mostly in the form of monophthongization, can also lead to different words and make the listener confused. The errors can be seen in the word 'vary' [veərI], pronounced as [feri]. This error will drive the listener to misunderstand since [feri] is the way to pronounce the word 'ferry'. Besides, the word 'great'[greit] was pronounced as [grit]. This error will make the listener refer to the word 'greet' since [grit] is closed to the pronunciation of the word 'greet'. The last is the word 'tie' [tar] which was pronounced as [ti:]. This error is the exact pronunciation of the word 'tea', so the listener will be confused by the existence of this error.

The errors in triphthongs as shown by the table, revealed that instead of pronouncing [I] and $[\mho]$ in the middle of triphthong, the teachers tend to pronounce them with glides [j] and [w] respectively. This means that teachers still have difficulties pronouncing triphthong due to the nonexistence of triphthong in teachers' first language. The glides [j] and [w] were generated to ease their pronunciation. Such errors may show the inaccuracy of teachers' pronunciation in comprehending English sounds.

The findings indicate that the teachers made errors in various forms of vowels sounds. Besides, the errors lead to different words with a different meaning from the intended words to confuse the listeners. This means that the teachers are less intelligible, which can cause misunderstanding when communicating in English. Listeners' ease of understanding is one of the factors that may affect intelligibility (Behrman, 2017), whereas the realistic goal of pronunciation is the listeners' understanding or intelligibility (Derwing \& Munro, 2005). Moreover, as the teachers are the EFL young learners' role model especially in pronunciation, similar errors can be produced by the learners since their main learning style is imitating. As a result, the learners' pronunciation will have troubles and their English may fail to improve. Therefore, the teachers' errors in pronunciation should be minimized especially when teaching their students to avoid similar errors transferred to their students.

\section{Factors Affecting Pronunciation Errors}

Moedjito (2016) discloses that Indonesian students' and teachers' perceptions on pronunciation difficulty lie on several issues, namely the non-existent English sounds in students' native language, teachers are hesitant to teach pronunciation, English and students' first language have similar sounds. Yet, their distribution is different, and that the same spelling is not always pronounced in the same way. Some of these factors are explored in this research which triggers the production of error. Yet, the factors in this research are classified into two categories, namely linguistics factors and non-linguistic factors. The linguistic factors are investigated by analyzing the produced errors, including interlingual transfer (interference), intralingual transfer (overgeneralization), pronunciation difference between grapheme and sound, hypercorrection, and words similarity. Meanwhile, the non-linguistic factors are analyzed from the given questionnaires, consisting of educational background and teachers' lack of English practice. The following teachers' profiles taken from the questionnaire should be looked at closely before understanding the factors.

The following table shows that there are three male and 17 female teachers involved. Sixteen teachers were between 22-30 years old, and the others were 31-42 years old. The teachers' mother tongue is mostly Javanese, while two other teachers speak other local languages. Most of them have taught English at elementary schools for 1-5 years, yet four teachers had 6-10 years of teaching experience. The teachers have a hectic teaching schedule with up to 18 classes in a week. Besides, seven teachers hold a bachelor's degrees other than English education majors, yet 13 graduated from English education. 
Table 3. The Teachers' Profile

\begin{tabular}{lll}
\hline Teachers' profile & Range/types & Total \\
\hline Age & $31-42$ & 4 \\
& $22-30$ & 16 \\
Sex & Male & 3 \\
\multirow{2}{*}{ Mother tongue } & Female & 17 \\
\multirow{3}{*}{ Years of teaching } & Javanese & 18 \\
\multirow{4}{*}{ Teaching load per week } & Indonesian & 2 \\
& 1-5 years & 16 \\
Education background classes & 4 \\
& 11-18 classes & 14 \\
& English education & 13 \\
& Other majors & 7
\end{tabular}

\section{Interlingual Transfer (Interference)}

Pronunciation errors caused by interlingual transfer or interference occur in English vowels that do not exist in participants' first languages (L1), namely Indonesian and Javanese languages. It means that the teachers use the phonological system of Javanese and Indonesian when pronouncing English vowels. This is also due to the inability of the teachers to produce vowel sounds in English correctly.

Interlingual transfer in monophthong occurs in [i:], [æ], [a:], [u:], [p], [ $\Lambda$ ], [3:], and [॰:] that do not exist in the teachers' L1 and were mispronounced with other sounds that are closed in the phonological system with them. Meanwhile, Interlingual transfer in diphthong is reflected by [eə],

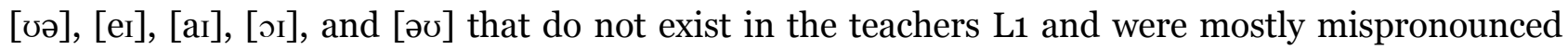
with monophthongs to ease the way they pronounce the English sounds. In addition, interlingual transfer in triphthong can be observed from the pronunciation errors of [v] and [I] in the middle of triphthong, which is pronounced as glides [w] and [j] because the teachers L1 do not have any triphthongs so that the glides are produced to ease their English pronunciation. The following table describes the examples of pronunciation errors caused by the interference of Indonesian and Javanese in monophthong, diphthong, and triphthong.

Table 4. Errors of Interlingual Transfer

\begin{tabular}{|c|c|c|c|}
\hline $\begin{array}{l}\text { Orthographic } \\
\text { transcription }\end{array}$ & $\begin{array}{c}\text { Phonetic } \\
\text { transcription }\end{array}$ & Produced sounds & Vowels Errors \\
\hline attic & [ætık] & [etik] & {$[æ] \rightarrow[\mathrm{e}]$} \\
\hline wheel & [wi:l] & [wil] & {$[\mathrm{i}:] \rightarrow[\mathrm{I}]$} \\
\hline car & [ka:] & [kar] & {$[\mathrm{a}:] \rightarrow[\mathrm{a}]$} \\
\hline ooze & [u:z] & [us] & {$[\mathrm{u}:] \rightarrow[\mathrm{u}]$} \\
\hline hot & [hot] & [hot] & {$[\mathrm{p}] \rightarrow[\mathrm{o}]$} \\
\hline utter & {$[\Lambda$ tə] } & [atər] & {$[\Lambda] \rightarrow[\mathrm{a}]$} \\
\hline work & [w3:k] & [wək] & {$[3:] \rightarrow[\partial]$} \\
\hline autumn & [っ:təm] & [otəm] & {$[0:] \rightarrow[0]$} \\
\hline aeroplane & [eərəpleın] & [eroplen] & {$[\mathrm{e}] \rightarrow[\mathrm{e}]$} \\
\hline curious & [kjuərıəs] & [kərıəs] & {$\left[{ }^{\prime}\right] \rightarrow[\partial]$} \\
\hline eight & [eit] & [et] & {$[\mathrm{eI}] \rightarrow[\mathrm{e}]$} \\
\hline island & [arlənd] & aislənd] & [aI] $\rightarrow$ [ai] \\
\hline home & [həชm] & [hom] & {$[\partial \mho] \rightarrow[\mho]$} \\
\hline oil & [orl] & [oil $]$ & [ЈI $] \rightarrow[\mathrm{oi}]$ \\
\hline royal & [roıəl] & [rojəl] & [эә] $\rightarrow[$ ๖јә] \\
\hline flower & [flavə] & [flawər] & {$[$ avə] $\rightarrow[$ awə] } \\
\hline layer & [leıə] & [lejər] & [елә] $\rightarrow$ [ејə] \\
\hline giant & [dzaiənt] & [dzajənt] & [агә] $\rightarrow$ [ајə] \\
\hline lower & [lәуә] & [lawər] & [ə兀ә] $\rightarrow[$ awə] \\
\hline
\end{tabular}


Table 4. shows monophthongs [i:] and [æ] that do not exist in participants' L1 are pronounced as [I] and [e] respectively because [I] and [e] exist in their L1 and closed to [i:] and [æ] in the English phonological system. Also, diphthong [ซə] and [eI] were pronounced as [ə] and [e] respectively as the respondents' L1 does not recognize these diphthongs so that they pronounce these diphthongs as [e], which have the closest phonological system to the diphthong to ease their pronunciation. Moreover, triphthong [эг] and [ајə] were pronounced as [əjə] and [awə] as the participants' L1 does not have any triphthongs, so that glides [w] and [j] were generated in the middle of the triphthong to make the pronunciation easier.

\section{Intralingual Transfer (Over-generalization)}

Brown (2008) mentions that the negative equivalent of intralingual transfer is overgeneralization. Intralingual transfer occurs when one starts acquiring new systems in the target language so that she/he turns to over-generalize the system. Hanafi (2014) adds that one's previous knowledge of the foreign language is used in over-generalization. Also, Heydari \& Bagheri (2012) state that overgeneralization arises when a deviant structure based on other structures in the second language is generated. In this study, pronunciation errors caused by interlingual transfer are in the form of sound that has similarities with the writings of other sounds in the target language, English. The teachers generalize a grapheme (letter) excessively to the specified sound. The over-generalized forms of graphemes found in this study are $\langle$ ea $\rangle,\langle\mathrm{i}\rangle,\langle\mathrm{a}\rangle,\langle\mathrm{oO}\rangle,\langle\mathrm{u}\rangle$, and $<$ ee>.

Table 5. Errors of Intralingual Transfer

\begin{tabular}{|c|c|c|c|}
\hline $\begin{array}{l}\text { Orthographic } \\
\text { transcription }\end{array}$ & Phonetic transcription & $\begin{array}{c}\text { Produced } \\
\text { sounds }\end{array}$ & $\begin{array}{c}\text { Produced } \\
\text { Errors }\end{array}$ \\
\hline idiot & [Idiət] & [ardiət] & $<\mathrm{i}>\rightarrow[\mathrm{aI}]$ \\
\hline attic & [ætık] & [ətik] & $<\mathrm{a}>\rightarrow[\partial]$ \\
\hline poor & [рәә] & [pu:r] & $<\mathrm{OO}\rangle \rightarrow[\mathrm{u}:]$ \\
\hline fur & {$\left[\mathrm{f}_{3}:\right]$} & [fjur] & $<\mathrm{u}>\rightarrow[\mathrm{ju}:]$ \\
\hline toy & [tor $]$ & [tpI] & $<\mathrm{O}>\rightarrow[\mathrm{p}]$ \\
\hline deer & [diə] & [di:r] & $<\mathrm{ee}>\rightarrow[\mathrm{i}:]$ \\
\hline
\end{tabular}

As presented in Table 5, the teachers tend to over-generalize the pronunciation of the English grapheme that they are familiar with in pronouncing different English words. The grapheme <ae> as in 'breath'[bre $\theta$ ] is pronounced as [i:] since the teachers are familiar with the grapheme $<$ ae $>$ in the pronunciation of words like 'meat' [mi:t]. The grapheme $<\mathrm{i}>$ as in 'idiot' [Idrət] is pronounced as [ar] because the teachers used to pronounce it the same way as in pronouncing 'idol' [ardəl]. The grapheme <a>as in 'attic'[ætık] is over-generalized to [ə] since the teachers are familiar with the pronunciation of the grapheme in words like 'ago' [əgəə]. The grapheme <oo $>$ as in 'poor' [pvə] is pronounced as [u:] due to the teachers' familiarity with the pronunciation of such grapheme in the words like 'room' [ru:m]. The grapheme $<\mathrm{u}>$ as in 'fur' [f3:] is pronounced as [ju:] because the teachers used to pronounce it the same way as in pronouncing 'cute' [kju:t]. The grapheme <ee $>$ as in 'deer' [diə] is pronounced as [i:] since the teachers are familiar with the grapheme <ee $>$ in the pronunciation of words like 'meet' [mi:t].

\section{Pronunciation Difference between Grapheme and Sound}

Vowels sounds in English are pronounced differently with the way it is written orthographically. It might be why English is known as the language that has inconsistency in the pronunciation of a grapheme (letter). This differentiation drives the teachers to have some difficulties in pronouncing English vowels so that errors are produced. It is because the teachers' first languages do not apply the same thing. The pronunciation errors caused by the factors of the difference between grapheme with its sounds can be seen as follows. 
Table 6. Errors of Pronunciation Difference between Grapheme and Sound

\begin{tabular}{|c|c|c|c|}
\hline $\begin{array}{l}\text { Orthographic } \\
\text { transcription }\end{array}$ & Phonetic transcription & $\begin{array}{c}\text { Produced } \\
\text { sounds }\end{array}$ & Produced Errors \\
\hline flea & [fli:] & [flea] & $<\mathrm{ea}>[\mathrm{i}:] \rightarrow[\mathrm{ea}]$ \\
\hline banana & [bənana] & [banana] & $<\mathrm{a}>[\partial] \rightarrow[\mathrm{a}]$ \\
\hline replay & [ri:pleI] & [riplai] & $<\mathrm{ay}>[\mathrm{eI}] \rightarrow[\mathrm{aI}]$ \\
\hline house & [havs] & [hous] & $<\mathrm{ou}>[\mathrm{a} v] \rightarrow[\mathrm{ou}]$ \\
\hline cow & [kav] & [kov] & $<\mathrm{ow}>[\mathrm{av}] \rightarrow[\mathrm{ov}]$ \\
\hline layer & [leıә] & [lajər] & $<$ aye $>$ [елә] $\rightarrow$ [ajə] \\
\hline iron & [агәn] & [airon] & $<$ iro $>$ [анə] $\rightarrow$ [airo] \\
\hline flower & [flavə] & [flowər] & $<$ owe $>$ [avə] $\rightarrow$ [owə] \\
\hline royal & [rorəl] & [rojal] & $<$ оуа $>$ [оә] $\rightarrow$ [оја] \\
\hline
\end{tabular}

Table 6. proves the teachers pronounce the English vowels exactly just the way they are written. This means that they apply the same technique as they pronounce their L1. Instead of pronouncing the word "flea" as [fli:], they pronounce it as the way they read it in their L1 or as it is written which becomes [flea] where grapheme <ae> is pronounced as it is written [ea]. So as in word 'replay' [ri:pleI] which they pronounce as [riplar] because grapheme <ay> is pronounced as [ar] in the teachers' L1. It also happens in words with triphthong such as 'royal' [rorəl], which they pronounce as [rojal] just like they pronounce it in their L1 where grapheme <oya> is pronounced as [oja].

\section{Hypercorrection}

In many errors produced, the teachers sound cautious of making mistakes. It makes the sound production result from hypercorrection toward their pronunciation for the sake of producing correct pronunciation. Pronunciation errors due to such reasons are considered as a hypercorrection. Eckman et al. (2013) define hypercorrection as expanding a linguistic type outside its usual application, often contributing to incorrect output. It refers to the transfer of a linguistic form beyond the linguistic form intended by the speaker. It usually occurs in second language learning, when the learner tries to use the standard form in the target language, but its use is too excessive to produce other forms that do not appear in the standard form. In this study, errors in the form of hypercorrection occur in the pronunciation of a grapheme that is pronounced excessively. The productions of the sounds do not have any similarities or closeness with the grapheme itself. Also, the sounds produced do not exist in the teachers' first language.

Table 7. Errors of Hypercorrection

\begin{tabular}{|c|c|c|c|}
\hline $\begin{array}{l}\text { Orthographic } \\
\text { transcription }\end{array}$ & Phonetic transcription & Produced sounds & Produced Errors \\
\hline breath & [bre $\theta]$ & [bræ $\theta$ ] & $<\mathrm{ea}>[\mathrm{e}] \rightarrow[æ]$ \\
\hline aunt & [a:nt] & [ount] & $<\mathrm{au}>[\mathrm{a}:] \rightarrow[\mathrm{ov}]$ \\
\hline rude & [ru:d] & [rod] & $<\mathrm{u}>[\mathrm{u}:] \rightarrow[\mathrm{o}]$ \\
\hline white & [wait] & [weit] & $<\mathrm{i}>[\mathrm{aI}] \rightarrow[\mathrm{eI}]$ \\
\hline home & [həom] & [houm] & $<0>[\partial \mho] \rightarrow[0 \mho]$ \\
\hline
\end{tabular}

As presented in table 7, the errors produced by the teachers are beyond the target sounds, which are not even closed with the intended sounds. The produced sounds do not exist in their L1 and are considered difficult to pronounce. This happens in 'breath' [bre $\theta$ ] which is pronounced as [bræ $\theta$ ]. The error explains that monophthong [e] is pronounced as [æ]. Monophthong [æ] does not exist in Indonesian phonology, neither does it in any local languages in Indonesia, so that it is normally difficult to pronounce by the teachers. However, the monophthong [æ] is produced due to avoiding making mistakes due to excessive pronunciation to the monophthong [e]. Moreover, they pronounce 'aunt' [a:nt] as [ount], where the monophthong [a:] is pronounced as [ov], which is not included in any monophthong. The two sounds do not have any similarities at all. The findings indicate that the teachers try to pronounce the sounds correctly in the target language. However, 
the pronunciation is too excessive, generating other sounds that are normally difficult to pronounce and are not even close to the target sounds.

\section{Words Similarity}

There is no correlation between written and spoken words in English since English words are not usually spoken as they are written (Astuti et al., 2021). The similarity between words can be the cause of pronunciation errors. Word similarity can be characterized by the number of words syllables, letters, and similar sounds in a word pair. Here are the examples of the errors.

Table 8. Errors of words similarity

\begin{tabular}{|c|c|c|c|}
\hline Orthographic transcription & Phonetic transcription & Produced sounds & Similar Words \\
\hline elephant & [elıfənt] & [iləpent] & eleven [I'levn] \\
\hline heart & [ha:t] & [hз:t] & hurt [hз:t] \\
\hline rude & [ru:d] & [rod] & road [rəod] \\
\hline dawn & [do:n] & [daon] & down [daon] \\
\hline law & [l॰:] & [ləə] & low [ləઇ] \\
\hline work & [w3:k] & [wok] & walk [wo:k] \\
\hline vary & [veərI] & [verI] & very [verI] \\
\hline tie & [tai $]$ & [ti:] & tea [ti:] \\
\hline
\end{tabular}

Table 8. presents that the teachers produced errors whenever they pronounced English vowels due to their perception of similar words. The sound [e] as in word 'elephant' [elifənt] was pronounced as [i] that becomes [iləpent] because the teachers were influenced by the word 'eleven'[r'levn]. Similarly, this occurs whenever they pronounce the sound [a:] in word 'heart' [ha:t] as [3:] that becomes [h3:t] since they are distracted by the word 'hurt' [h3:t]. This production also occurred when they pronounced the words 'rude', 'dawn', 'law', 'work', 'vary', and 'tie' that are affected by other similar words.

\section{Educational Background}

In table 3., it is known that six teachers have no English education background. Zein (2012) mentioned that both primary teachers with and without English education experienced pronunciation problems due to their heavy local accents. Nevertheless, this research tried to dig this issue further. Based on the analysis conducted, it was found that teachers with no English education background tend to produce more pronunciation errors that could lead to different words or meanings. For instance, the teachers without English education background pronounced the word wheel [wi:l] as [wel] well. Meanwhile, the teachers who graduated from the English study program only made few errors, and it occurs in the sounds that do not exist in their first languages, and the errors are not varied.

Though both groups of teachers encountered pronunciation problems and produced errors in pronunciation, teachers with no English education background produced more errors. This shows the existence of differences in pronunciation errors produced by English graduated teachers and non-English graduated teachers. It also uncovers that non-English graduated teachers have lower English proficiency. Habibi \& Sofwan (2015) confirm that the teachers, those not from English majors, obtained low scores in English Proficiency Test that they took. Furthermore, Asriyanti et al. (2013) point out these teachers will not be able to acquire the required learning skills needed, to use different approaches and techniques to educate young learners, to produce useful content, to make English available to very young learners, and to use relevant, authentic materials to teach young learners. Thus, it is noticeable that educational background affects teachers' English proficiency as well as pronunciation ability.

\section{Teachers' Lack of English Practice}

The study finds the teachers have up to 18 classes in a week. It indicates the limited time they get to increase their English ability since most of their time is spent teaching and preparing for the materials. As a result, they use their English only when they teach, and they are unconfident due to inadequate practice. Sulistiyo (2016) confirms that the teachers feel uncomfortable in both 
speaking and writing in English. Moreover, in the data analysis, it is found that the [e] in breath [bre $\theta]$ was pronounced correctly only by seven teachers. Meanwhile, the teachers could pronounce [e] properly in other words. Besides, [e] exist in teachers' first languages, so that the teachers are supposed to be able to pronounce it well in various words. It indicates that such errors are produced due to the teachers' unfamiliarity with the words. This error may not be generated if the teachers provide more time to practice their English to become more familiar with English sounds.

\section{CONCLUSION}

From the analysis conducted, it can be concluded that the pronunciation errors in the English segmented vowels produced by the elementary school English teacher in Yogyakarta are varied in the forms of monophthongs, diphthongs, and triphthongs. The errors in monophthongs mostly occur in the sounds that do not exist in the teachers' L1. They are [i:], [æ], [a:], [u:], [p], [ᄉ], [3:], and [o:]. The errors in diphthong are frequently pronounced as monophthong. Most of the errors in triphthong occur on [v] and [I] in the middle of triphthong, which was pronounced as glides [w] and [j]. Moreover, many of the errors could lead to other words and confuse listeners, indicating that teachers' pronunciation is less intelligible. Meanwhile, the cause of the errors on linguistic factors belongs to interlingual transfer, intralingual transfer, pronunciation difference between grapheme and sound, hypercorrection, and words similarities. In contrast, non-linguistic factors belong to educational background and teachers' habits. From the two factors, it is known that linguistic factors have a greater influence on teacher pronunciation errors, mainly caused by interlingual transfer factors with various forms of errors.

The research signifies that the teaching of EFL to young Indonesian learners in terms of teachers' competence is rather apprehensive. It discloses the teachers' pronunciation ability which has several rooms for improvement. Yet, it does not declare that the teachers should have nativelike pronunciation. Instead, it concerns the learners' failure in mastering English comprehensibly, which can be induced by teachers' errors in producing English sounds when communicating with the students since most teachers are learners' main model in learning English. Therefore, it is required for young Indonesian learners to have competent English teachers, and Indonesian schools' policymakers should fully watch EFL teaching to young learners to ensure that the teachers obtain this criterion. In addition, the teachers are suggested to improve their pronunciation ability by frequently practicing their pronunciation and having intensive pronunciation training to have more intelligible pronunciation and teach better English to their learners.

\section{REFERENCES}

Al Mafalees, F. A. M. (2020). Mispronunciation of English Consonant Sounds by Yemeni EFL Learners at Secondary Schools: An Analysis of the Problems and Some Remedies. Language in India , 20(1), 108-122. www.languageinindia.com

Arikan, A., \& Yilmaz, A. F. (2020). Pre-Service English Language Teachers' Problematic Sounds. International E-Journal of Educational Studies (IEJES), 4(7), 1-26. https://doi.org/10.31458/iejes.594715

Astuti, W., Basri, H., Syafar, A., \& Suriaman, A. (2021). Error Analysis of Silent Letters and Its Relevance to the Teaching of English. Proceedings of the 5th International Conference on Arts Language and Culture (ICALC 2020), 534(534), 153-158. https://doi.org/10.2991/assehr.k.210226.061

Begum, A., \& Hoque, M. A. (2016). English Pronunciation Problems of the Tertiary Level Students in Bangladesh: a Case Study. Researchers World: Journal of Arts, Science and Commerce, VII(4), 50-61. https://doi.org/10.18843/rwjasc/v7i4/o6

Behrman, A. (2017). A clear speech approach to accent management. American Journal of SpeechLanguage Pathology, 26(4), 1178-1192. https://doi.org/10.1044/2017_AJSLP-16-0177

Brown, H. D. (2008). Prinsip Pembelajaran dan Pengajaran Bahasa (ke-5). Kedutaan Besar Amerika Serikat. 
Çakır, İ., \& Baytar, B. (2014). Foreign language learners' views on the importance of learning the target language pronunciation. Journal of Language and Linguistic Studies, 10(1), 99-110. www.jlls.org

Creswell, J. W. (2014). Research Design: Qualitative, Quantitative, and Mixed Methods Approaches (4th ed.). SAGE Publication lnc.

Demirezen, M. (2007). Identity Problems of Non-native Teachers of English in Teacher Education. The Internet TESL Journal, 13(8). http://iteslj.org/Articles/DemirezenNonNativeTeachers.html

Derwing, T. M., \& Munro, M. J. (2005). Second Language Accent and Pronunciation Teaching: A Research-Based Approach. TESOL Quarterly, 39(3). https://doi.org/10.2307/3588486

Dulay, H., Burt, M., \& Krashen, S. (1982). Language Two. Oxford University Press.

Eckman, F. R., Iverson, G. K., \& Song, J. Y. (2013). The role of hypercorrection in the acquisition of L2 phonemic contrasts. Second Language Research, 29(3), 257-283. https://doi.org/10.1177/0267658312467029

Ellis, R. (1997). Review of Second language acquisition. Oxford University Press.

Habibi, A., \& Sofwan, M. (2015). Teachers of English for Young Learners : An Analysis on Their English Proficiency and Profile. English Education Study Program-National Seminar, Oktober.

Haidara, Y. (2016). Psychological Factor Affecting English Speaking Performance for the English Learners in Indonesia. Universal Journal of Educational Research, 4(7), 1501-1505. https://doi.org/10.13189/ujer.2016.040701

Hamad Alzinaidi, M., \& M. M. Abdel Latif, M. (2019). Diagnosing Saudi Students' English Consonant Pronunciation Errors. Arab World English Journal, 10(4), 180-193. https://doi.org/10.24093/awej/vol1ono4.14

Hanafi, A. (2014). the Second Language Influence on Foreign Language Learners' Errors : the Case of the French Language for Algerian Students Learning English As a Foreign Language. European Scientific Journal, 2(June), 30-38.

Heydari, P., \& Bagheri, M. S. (2012). Error analysis: Sources of L2 learners' errors. Theory and Practice in Language Studies, 2(8), 1583-1589. https://doi.org/10.4304/tpls.2.8.1583-1589

Hornby, A. S. (1995). Oxford Advanced Learner's Dictionary of Current English (5th ed.). Oxford University Press.

Hunt-Gómez, C. I., \& Navarro-Pablo, M. (2020). Analysis of Pre-Service Foreign Language Teachers' Incorrect Articulations: Frequency, Influence on Communication, and a Specific Corrective Strategy. Problems of Education in the 21st Century, 78(6), 933-947. https://doi.org/10.33225/pec/20.78.933

Irianto, N. A., Imranuddin, \& S, S. (2018). An Analysis of Pronunciation Errors of English Consonants: $/ \theta /$ and $/ ð /$ by the Students of the English Education Study Program of University of Bengkulu. Journal of English Education and Teaching (JEET), 2(3), 18-28.

James, C. (1998). Errors in language learning and use: Exploring Error Analysis. Longman.

Jazuly, A., \& Indrayani, N. (2018). Guidance of Teaching English to Young Learners (TEYL) for Early Childhood Education Teachers at Ad Dhuha Kindergarten of Jember. Linguistic, English Education and Art (LEEA) Journal, 1(2), 168-179. https://doi.org/10.31539/leea.v1i2.175

Kesuma, T. M. J. (2007). Pengantar (Metode) Penelitian Bahasa. Carasvatibooks.

Lenneberg, E. (1967). Biological foundations of language. Wiley.

Marsono. (2013). Fonetik. Gadjah Mada University Press.

Moedjito. (2016). The Teaching of English Pronunciation: Perceptions of Indonesian School Teachers and University Students. English Language Teaching, 9(6), 30. https://doi.org/10.5539/elt.v9n6p30

Moedjito. (2017). Improving EFL Learners' Pronunciation of English through QuizDemonstration-Practice-Revision (QDPR). English Language Teaching, 11(1), 10-20. https://doi.org/10.5539/elt.v11n1p10

Moedjito, \& Harumi, I. T. O. (2008). Perceptions of the Seriousness of Mispronunciations of $\begin{array}{llll}\text { English Speech } \quad \text { Sounds. TEFLIN Journal, 19(1), } & \text { 70-92. }\end{array}$ https://doi.org/10.15639/teflinjournal.v19i1/70-92

Mulansari, I., Basri, H., \& Hastini. (2014). The Analysis of The First Year Students ' Errors in Pronouncing English Words. E-Journal of English Language Teaching Society (ELTS), 2(3), 
1-16. http://jurnal.untad.ac.id/jurnal/index.php/ELTS/article/view/3048/2121

Osatananda, V., \& Salarat, P. (2020). The tolerance of English instructors towards the Thaiaccented English and grammatical errors. Indonesian Journal of Applied Linguistics, 9(3), 685-694. https://doi.org/10.17509/ijal.v9i3.23219

Pateda, M. (1989). Analisis Kesalahan. Nusa Indah.

Penfield, W., \& Roberts, L. (1959). Speech and brain mechanisms. Princeton University Press.

Pourhosein Gilakjani, A., \& Sabouri, N. B. (2016). Why Is English Pronunciation Ignored by EFL Teachers in Their Classes? International Journal of English Linguistics, 6(6), 195. https://doi.org/10.5539/ijel.v6n6p195

Ramasari, M. (2017). Students Pronounciation Error Made in Speaking for General Communication. Linguistic, English Education and Art (LEEA) Journal, 1(1), 37-48. https://doi.org/10.31539/leea.v1i1.32

Renandya, W. A., Hamied, F. A., \& Nurkamto, J. (2018). English language proficiency in Indonesia: Issues and prospects. Journal of Asia TEFL, 15(3), 618-629. https://doi.org/10.18823/asiatefl.2018.15.3.4.618

Roach, P. J. (1998). English Phonetics and Phonology: A Practical Course (2nd Editio). Cambridge University Press.

Sikki, E. A. A., Rahman, A., Hamra, A., \& Noni, N. (2013). The Competence of Primary School English Teachers in Indonesia. Journal of Education and Practice, 4(11), 139-146.

Skandera, P., \& Burleigh, P. (2005). A Manual of English Phonetics and Phonology. Narr Francke Attempto Verlag.

Sulistiyo, U. (2016). English Language Teaching and EFL Teacher Competence in Indonesia. Proceedings of ISELT FBS Universitas Negeri Padang, 396-406. http://ejournal.unp.ac.id/index.php/selt/article/view/7001

Utulu, D. C. (2014). Monophthongisation and Vowel Lengthening Processes in Educated Urhobo English : A Moraic Account. Arts and Design Studies, 26, 1-10.

Zein, Mochamad Subhan. (2017). Elementary English education in Indonesia: Policy developments, current practices, and future prospects. English Today, 33(1), 53-59. https://doi.org/10.1017/So266078416000407

Zein, Muchamad Subhan. (2012). Language teacher education for primary school English teachers in Indonesia: Policy recommendations. PhD Thesis(December), 364. 